\title{
Early and Late Embryonic Loss of Smallholder Synchronized Dairy Cows Within Ethiopia
}

\author{
Bainesagn Worku ${ }^{1, *}$, Million Tadesse ${ }^{1}$, Azage Tegegne ${ }^{2}$ \\ ${ }^{1}$ Ethiopian Institute of Agricultural Research Center, Holeta, Ethiopia \\ ${ }^{2}$ International Livestock Research Institute (ILRI), Addis Ababa, Ethiopia
}

Email address:

baiworku@gmail.com (B. Worku), mill_tadsse@yahoo.com (M. Tadesse), a.tegegne@cgiar.org (A. Tegegne)

${ }^{*}$ Corresponding author

\section{To cite this article:}

Bainesagn Worku, Million Tadesse, Azage Tegegne. Early and Late Embryonic Loss of Smallholder Synchronized Dairy Cows Within Ethiopia. Cell Biology. Vol. 8, No. 1, 2020, pp. 1-7. doi: 10.11648/j.cb.20200801.11

Received: October 19, 2019; Accepted: November 26, 2019; Published: April 7, 2020

\begin{abstract}
This study was carried out on 53 cows selected from smallholder dairy farmers in the Ejerie, Adea Berga and Metarobi western Shoa of Oromia in Ethiopia. All of the cows were investigated in October and November, 2015 for their cyclicity, pregnancy and mainly for early embryonic mortality determination. Milk samples were collected from the 53 of synchronized lactating cows involved in the estrus synchronization programme at the time of AI (day 0). Out of lactating cows, 33 exhibited true heat but due heat detection error, only 26 lactating cows were inseminated in day AI (Artificial Insemination). After it was confirmed that 20 lactating cows were pregnant, then they were continued for further progesterone profiling starting from day 18 to 45 day of post AI at interval of 3 days for determination of early embryonic loss based on progesterone concentration. The milk sample was analyzed by Hormonost Farmer Test. Results of the study indicated that about $60 \%$ of lactating cows maintain pregnancy until 45 -day post $\mathrm{AI}$ whereas $15 \%, 15 \%$ and $10 \%$ of early pregnant lactating cow's loss their embryo at $21^{\text {st }}$ to $24^{\text {th }}$ days, $27^{\text {th }}$ to $30^{\text {th }}$ days and $33^{\text {rd }}$ day of post AI, respectively. The average progesterone concentration for pregnant cows was $24.46 \mathrm{ng} / \mathrm{ml}$ at day 21 to day 45 post AI. Based on finding of this result monitoring and evaluating reproductive traits with progesterone profiling is recommended to improve the fertility of dairy cattle. Finally, embryonic loss detection may serve as a basis for improvement of fertility of dairy cows mean while it will help for designing appropriate breeding management of dairy cattle.
\end{abstract}

Keywords: Embryonic Mortality, Milk Progesterone, Progesterone Profiling

\section{Introduction}

Embryo mortality refers to embryo losses during the period from fertilization to completion of the stage of differentiation, which in the cow occurs at approximately Day 45 of gestation [1]. Embryonic mortality (EM) is regarded as one of the causes of reproductive failure in cattle resulting in reduced pregnancy rates, slower genetic improvement and substantial financial losses to dairy production [2-4]. The timing of the embryonic loss is important and can have different effects on the level of production of a dairy farming enterprise [5]. Embryonic mortality is divided into early embryonic mortality and late embryonic mortality [6]. Early embryonic mortality occurs before day 18 post artificial insemination (AI) whereas late
Embryonic Mortality occurs between 19- and 45-days' post AI.

Identification of non-pregnant animals at the earliest day post-breeding is of prime importance for maintaining an optimum calving interval. Pregnancy diagnosis as early as possible after insemination helps in better management of pregnant animals and early submission of non-pregnant animals for subsequent breeding [7]. Although several methods like non-return to estrus, rectal examination, and ultrasonography are used to diagnose pregnancy in dairy animals, determination of progesterone concentration in milk before 45 days post-breeding/AI continue to be the most common and advanced method.

A lot of investigators have demonstrated the usefulness of measuring milk progesterone for monitoring the cow's reproductive status [8-11]. 
There is lack of adequate information on embryonic loss in dairy cows associated with various reasons in synchronized dairy cows in western areas of Oromia region. This study will help to fulfill this gap by availing updated information and skill in the areas for further improvement of diary animals. Therefore, the objective of this study was to investigate and characterize possibility of early and late embryonic loss of hormone synchronized smallholder lactating dairy cows under on farm condition and to determine the progesterone profile of pregnant and nonpregnant lactating cows on day 0 , day of $\mathrm{AI}$, day $10-12$, day 18 and day 21 up to 45 after breeding.

\section{Materials and Method}

\subsection{The Study Area and Animal Management}

This study was carried out on 53 cows selected at on farms small holder dairy farmers in the Ejere, Adea Berga and Metarobi western Shoa of Oromia in Ethiopia. They were selected randomly based on their body condition. All of the cows were investigated in October and November, 2015 for their cyclicity, pregnancy and mainly for early embryonic mortality determination.

The cross-breed cows were kept in roofed structures with open sides, whereas the indigenous cows were kept under free grazing lands. The crossbreed was fed a hay grass with supplementation of wheat and nuge cake. Local cows were mainly fed on grazing land with crop residue supplementation. Estrus detection was carried out by visual observation by the AI technicians. When signs of estrus were noticed, AI was performed by experienced technicians.

\subsection{Equipments and Chemicals}

Fertility Box Cow is an instrument which measures range of progesterone concentration from 1-30 ng/ml. Microtherme with separate adapter for $220 / 230 \mathrm{~V}$ and used for warming up milk diluter and substrate. Tube holder is custom-made for correct handling of special test tubes. $100 \mu$ l-pipettes were used for precise, quantitative sampling of milk and enzyme solutions. Carrying case protects all above Equipments from dust.

Disposable chemicals and materials such as Specific antibody coated Test tubes, Milk Diluter Enzyme, Substrate, two vials of controls, containing predetermined \& given concentrations of progesterone and Pipette tips were used. According Hormonost Farmer test the complete test kits were kept under Holleta Biotechnology and molecular scientific refrigerators adjusted at $4^{\circ} \mathrm{C}$.

Milk samples were collected from the 53 of total lactating cows involved in the estrus synchronization programme at the time of prostaglandin injection and only 26 out of 33 truly heat exhibited of lactating cows were inseminated at the AI (day 0). After milk progesterone evaluation at day 10, day 18 , and day 21 post AI, twenty lactating cows were confirmed as pregnant and then they were continued for further progesterone profiling starting from day 18 to days of post AI at interval of 3 days for determination of embryonic loss based on progesterone concentration. About 20-30ml whole milk sample was collected from individual cow by cleaned labeled jar. Then the collected milk samples from individual cows were taken to Holleta Biotechnology and molecular laboratory.

The milk sample was analyzed by Hormonost Farmer Test. Hormonost Farmer Test (quantitative rapid assay with test device Fertility Box Cow for determining progesterone content of milk samples of dairy cows) is a standard kitbased test manufactured by biolab $\mathrm{GmbH}$, munchen, Germen which determines milk progesterone concentration.

Experienced AI technicians were diagnosed the presence of CL through rectal palpation. The principle of milk samples collection at the time of AI (Day 0) were to determine on set of estrus cycle of the cow which is checking presence of CL during injection of prostaglandin based on $\mathrm{p} 4$ concentration. A concentration higher than $3 \mathrm{ng} / \mathrm{ml}$ was considered to indicate the presence of a functional $\mathrm{CL}$ and had passed estrus. Corpus Luteum regression was defined by a cow having a milk $\mathrm{P} 4$ concentration of greater $3 \mathrm{ng} / \mathrm{ml}$ at day $\mathrm{AI}$, which then declining to a level of less or equal to $3 \mathrm{ng} / \mathrm{ml}$ at the day the cow coming to estrous. The laboratory procedures were followed as per the standard protocol set by standard kit-based test manufactured by biolab $\mathrm{GmbH}$, munchen, Germen.

\subsection{Data Management and Statistical Analysis}

All data collected from laboratory were fed to Ms-Excel (2010). Progesterone profile was summarized and presented by using spread sheet Microsoft excel.

\section{Result and Discussion}

From the total prostaglandin treated, 53 lactating dairy cows, the milk samples were taken at the day of AI (day 0 ) for progesterone determination and 33 of them had shown progesterone concentration less than $3 \mathrm{ng} / \mathrm{ml}$. But in practical case 26 ( 24 cows from 1 st injection and 2 from second) of 33 were inseminated while the rest seven lactating cows were missed due to heat detection error by technicians.

The milk samples were collected at day of AI, 10-12, day 18 and day 21 of post AI for early pregnancy determination based on progesterone concentration. After day 18 post AI 20 lactating cows (which were pregnant) were continued for milk sample progesterone determination to detect embryonic loss until day 45 post $\mathrm{AI}$ at the interval of 3 days for each cow.

The progesterone concentration was continued to raise in $60 \%$ of 20 lactating cows on from day 21 to day 45 after post AI. The rest $40 \%$ of lactating cows were failed to maintain high progesterone concentration until day 45 of post AI at different days. Therefore, the result $60 \%$ of sampled lactating cows were become pregnant while, $15 \%, 15 \%$ and $10 \%$ of lactating cows were lost their embryo at $21^{\text {st }}$ to $24^{\text {th }}, 27^{\text {th }}$ and $30^{\text {th }}$ to $33^{\text {rd }}$ day of post AI, respectively. The embryonic mortality in this study disagree with result of $[12,13]$ which 
is 26 and $15.2 \%$. This might be due to variation estrus cycle between cows, poor nutrition during postpartum period and poor management [14]. The implication of the above for breeder was progesterone profiling could help to decide fertility management issues quickly. In breeding point of view progesterone concentration had a role to reinitiate AI and improve reproductive efficiency by decreasing the interval between AI services [15].

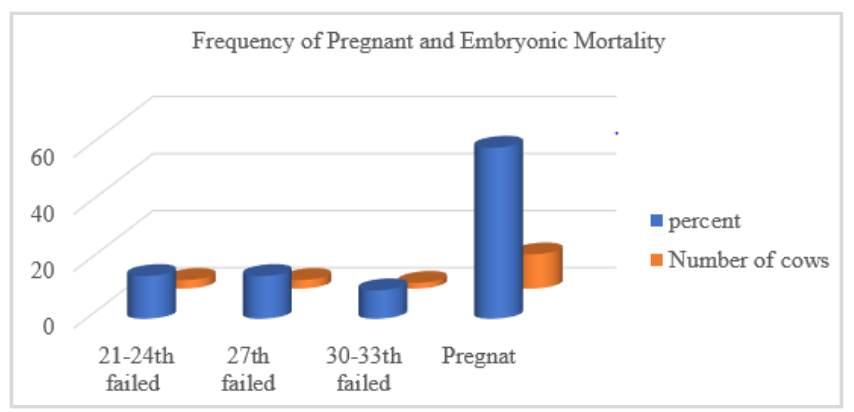

Figure 1. The proportion of pregnant and embryonically lost cows based on progesterone concentrations.

\subsection{Characterization of Embryonic Mortality Based on Individual Cow Progesterone}

Embryonic mortality, strictly interpreted, refer to fertility losses during the embryonic period, i.e. the period extending from conception to completion of the stage of differentiation which, in the cow, occurs at approximately 45 days [16].

Based on progesterone concentration profile in Figure 2 the embryonic loss of cows (C242, C282 and C618) could be categorized in early embryonic losses while, the other cows (C289, C293, and C288) cows which loss their embryo at $27^{\text {th }}$ day are categorized under late embryonic loss. Similarly, cows fail to maintain pregnancy at $30^{\text {th }}$ to $33^{\text {rd }}$ day after insemination are classified under late embryonic loss. This result was a little greater with the Studies [17-19] that early pregnancy diagnosis which indicate less than $15 \%$ of the viable embryos establish pregnancy by $27^{\text {th }}$ days after ovulation in lactating dairy cows while it was lower than that of beef cattle 69 and $83 \%$ of the frozen and fresh semen, respectively, establish pregnancy on day 37 of gestation.

In cow's maternal recognition of pregnancy occurs between day 16 and day 19 of pregnancy facilitated by the secretion of a trophoblast interferon bovine trophoblast protein -1 secreted by the conceptus between day 16 and day 26 of pregnancy identified as antiluteolytic agent in cattle [20]. So embryonic mortality can be detected through progesterone profile at the age of day 21 to 24 .

It is widely considered that an increase in the interval between service and return to estrus beyond the usual range of 17-25 days reflects embryonic mortality. Two sources of pregnancy failure exist after breeding, fertilization failure and pregnancy loss. When the interestrus or the interovulatory intervals are extended in bred animals, it usually indicates embryonic loss that occurred around the period of corpus luteum (CL) maintenance [21].

Experiments with continuous measurements of concentrations of progesterone in blood suggest that embryonic death at the time of CL maintenance delayed luteolysis, and extended interestrus interval [22]. Therefore, when embryonic death precedes luteolysis, luteal regression is delayed by at least 3 days after the end of pregnancy [23]. Thus, the result shows that $15 \%$ losses of pregnancy prior to day 24 and categorized under early embryonic losses embryonic losses, while $25 \%$ losses were grouped under late embryonic losses.

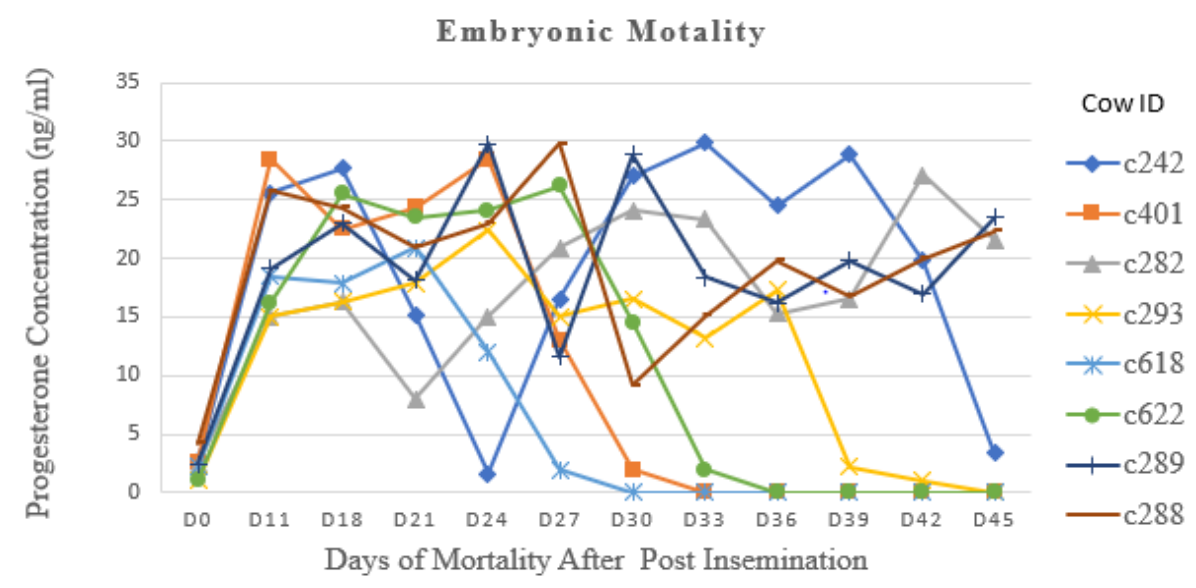

Figure 2. Pattern of milk progesterone concentration for embryonic lost lactating cows.

As it was shown in table 1 from a total of milk sampled local cows $33.33 \%$ of them were under incidence of embryonic mortality at different stage of embryo development based on progesterone concentration while $45.45 \%$ of crossed lactating cows were loss the embryo at stage of early pregnancy. In studies from California [24], it would appear that early embryo loss was greater in the modern high producing dairy cow and that a much higher proportion of the embryos after post AI compared with lower producing cows or heifers.

When embryo survival extends beyond the stage of maternal recognition of pregnancy, luteal regression was 
delayed, which results in a delayed return to estrus. [25] Suggested that returns to estrus after Day 24 could reflect embryonic losses occurring after Day 16 of gestation. Almost half $(47.5 \%)$ of the total recorded loss occurred between Days 28 and 42 of gestation. This result agrees with the report of [26] that more than half $(50 \%)$ of the total recorded loss occurred between Days 27 and 42 of gestation on late embryo in cattle that were managed on pasture-based systems.

Table 1. Pregnancies and embryonic loss within breed.

\begin{tabular}{|c|c|c|c|c|c|c|c|c|}
\hline \multirow{2}{*}{ Variables } & \multirow{2}{*}{\multicolumn{2}{|c|}{ Pregnant }} & & & \multicolumn{4}{|c|}{ Embryonic loss after post $\mathrm{AI}^{1}$} \\
\hline & & & \multicolumn{2}{|c|}{ Day 21-24 } & \multicolumn{2}{|c|}{ Day 27} & \multicolumn{2}{|c|}{ Day 30 to 33} \\
\hline Breed & $\mathbf{N}$ & $\%$ & $\mathbf{N}$ & $\%$ & $\mathbf{N}$ & $\%$ & $\mathbf{N}$ & $\%$ \\
\hline Cross & 6 & 54.55 & 2 & 18.18 & 2 & 18.18 & 1 & 9.09 \\
\hline Local & 6 & 66.67 & 1 & 11.1 & 1 & 11.1 & 1 & 11.1 \\
\hline Total & 12 & 60 & 3 & 15 & 3 & 15 & 2 & 10 \\
\hline
\end{tabular}

${ }^{1} \mathrm{AI}=$ Artificial Insemination

\subsection{Pattern of Progesterone Concentration for Pregnant Lactating}

Progesterone (P4) from the corpus luteum (CL) is critical for the establishment and maintenance of pregnancy and plays a major role in regulating endometrial secretions essential for stimulating and mediating changes in conceptus growth and differentiation throughout early pregnancy in ruminants [27]. Numerous studies have demonstrated an association between elevated P4 and acceleration in conceptus elongation [28, 29].

During the follicular phase, progesterone concentration was very low in milk (Figure 3 ). The actual p4 concentration for cows at estrus from milk samples collected ranged from less than $1 \mathrm{ng} / \mathrm{ml}$ to $2.7 \mathrm{ng} / \mathrm{ml}$. This result is in accordance of with the standard of the kit which is less than three for cows in estrus cows. In early embryonic development between day 10 to 12 , the progesterone concentration values were found progressively increased. The mean progesterone concentrations at day 10 to 18 were $21.83 \mathrm{ng} / \mathrm{ml}$ raging $16.3 \mathrm{ng} / \mathrm{ml}$ to $28.6 \mathrm{ng} / \mathrm{ml}$. According to Hormonost-Micro lab Farmer Test Standards, the cut-off point milk progesterone level for pregnant cow was $16 \mathrm{ng} / \mathrm{ml}$. From the results of milk samples collected lactating cows, the mean progesterone concentrations were $24.46 \mathrm{ng} / \mathrm{ml}$ at day 21 of post AI to until day 45. The minimum progesterone concentration was recorded as $16.3 \mathrm{ng} / \mathrm{ml}$ and the maximum progesterone concentration was observed as $29.9 \mathrm{ng} / \mathrm{ml}$ to maintain pregnancy.

Generally based on the milk progesterone test (Hormonost farmer test progesterone determination for fertility) 12 lactating cows were judged as pregnant and the rest 8 were not pregnant. Similarly, those cows were diagnosed by rectal palpation for pregnancy and the result was the same as the test. Finally, it was concluded that 12 lactating cows were pregnant and the pattern of progesterone concentration was sketched in (Figure 3).

\subsection{Use of Milk Progesterone Profile to Monitor Pregnancy and Embryonic Mortality}

If the cow was bred and becomes pregnant, progesterone in blood and milk remains high until just prior to calving. If the cow does not conceive, the corpus luteum begins to degenerate on approximately day 17 of the cycle, and progesterone declines to minimal concentrations on days 20 as the cow returns to heat. There was strong relationship between progesterone and embryo survival rate. Optimal progesterone concentrations between 7 and $8 \mathrm{ng} / \mathrm{mL}$ on 0 to 8 day were associated with maximal pregnancy rates, whereas concentrations that were lower or higher were associated with reduced fertility [30].
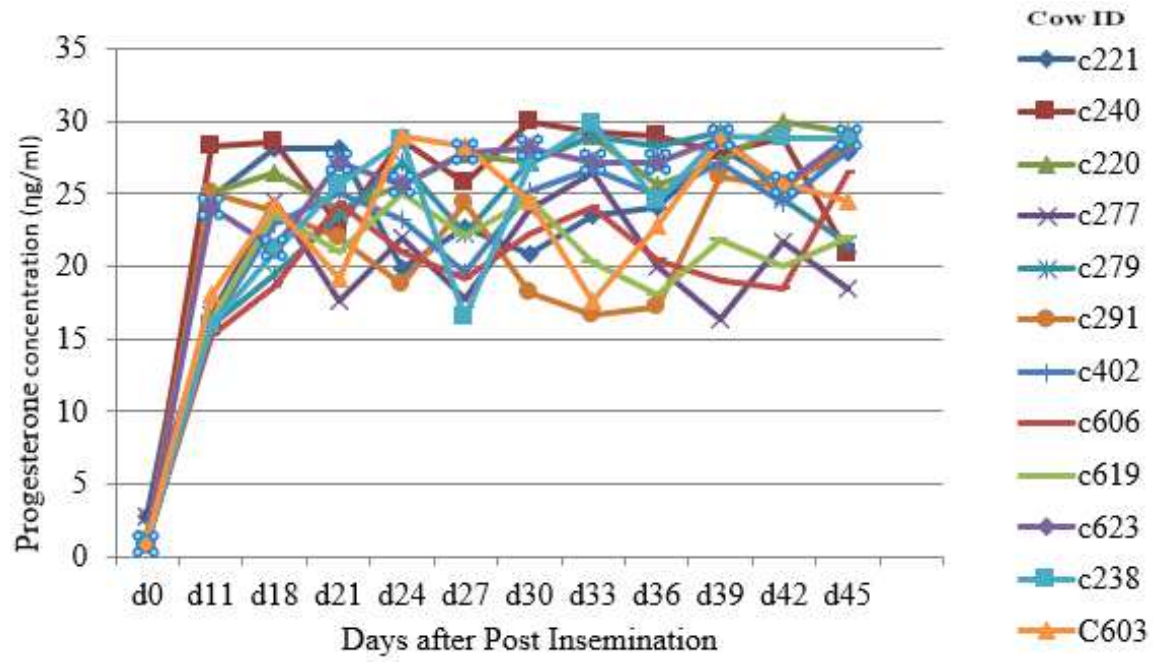

Figure 3. Pattern of milk progesterone individual cows' concentration in pregnant lactating cows at different days. 


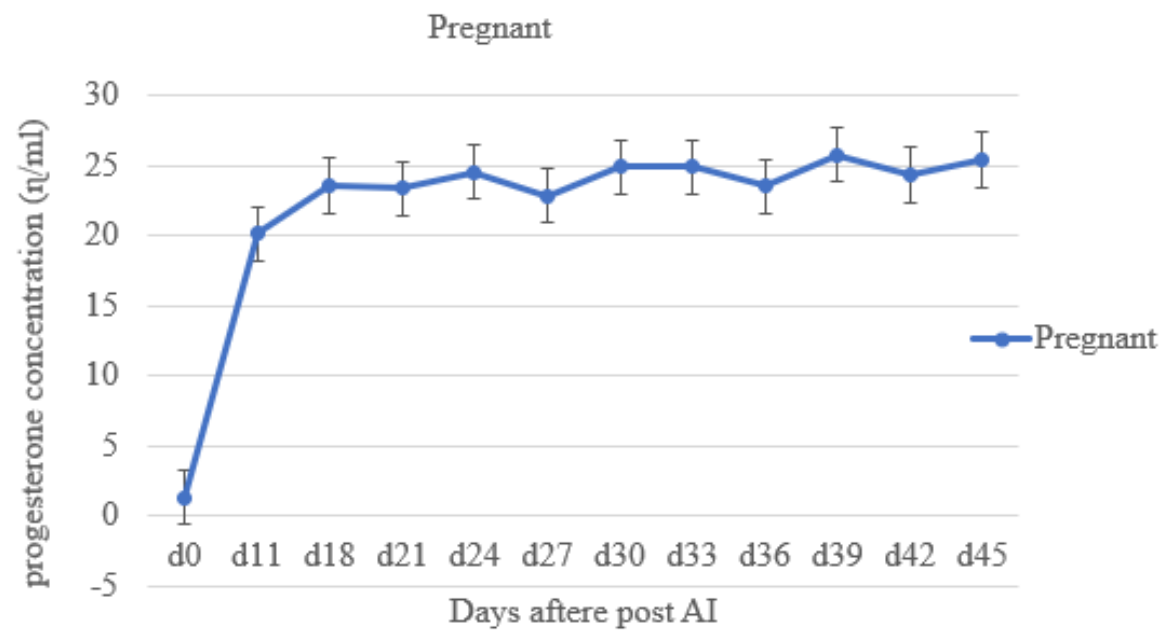

Figure 4. Pattern of average milk progesterone individual cows' concentration in pregnant lactating cows at different days.

From the figer below in pregnant cows mean progesterone concentrations rise from Day 11 to Day 42 to reach 16 to $25.41 \mathrm{ng} / \mathrm{mL}$. However, individual variations exist when measuring progesterone concentrations at different stages of pregnancy. This allows to use this system as a pregnancy test with corresponding positive and negative results of pregnancy results through trans rectal palpation. In the dairy, progesterone concentrations profile can be measured from
Day of AI till the end of pregnancy and can be used as reliable pregnancy test until 45 day. In case of late embryonic mortality associated with luteal maintenance, cows present detectable concentrations that are lower than critical level of the kit concomitant with a larger variation reflecting individual differences in the time at which embryonic death occurs.

\section{Progesterone Profile}

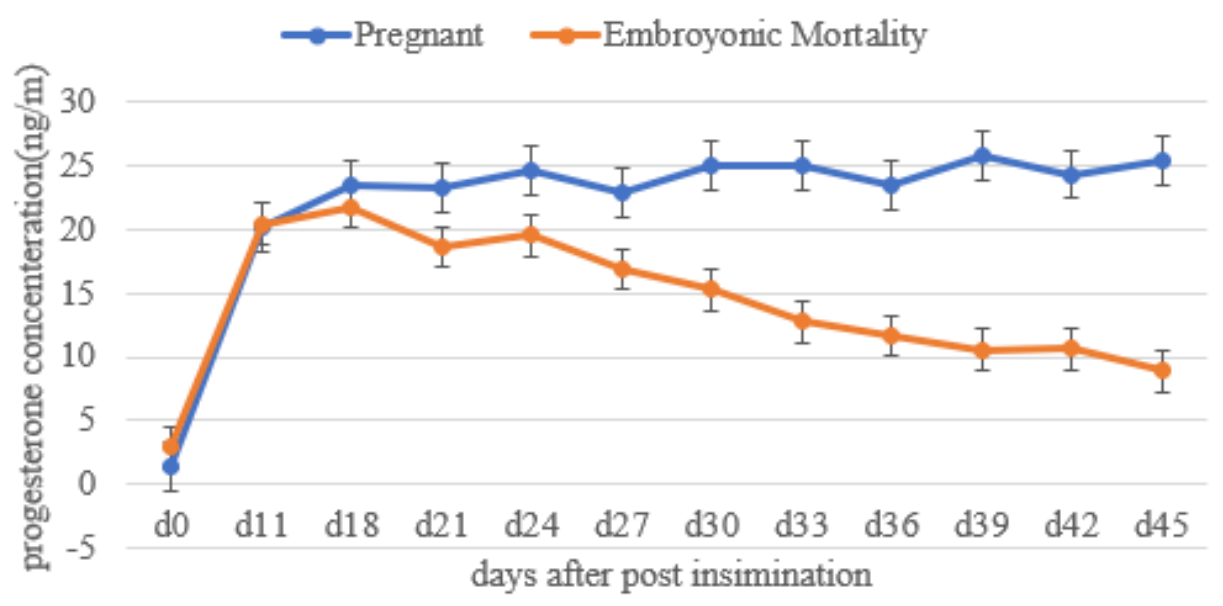

Figure 5. Average pregnant milk progesterone in contrast with Embryonic mortality cows at different days.

\section{Conclusion}

The result in this study indicates that progesterone concentration in lactating cows at day AI, day 11, day 18 and day 21 can help to judge either the cows pregnant or not pregnant at early stage. By using complete kits of the Hormonost farmer test early pregnancy and late pregnancy embryonic mortality were detected. From milk sampled lactating cows $40 \%$ of lactating cows that were confirmed to pregnant embryonic mortality occurred at different stage of pregnancy until 45 days. Therefore, it can be concluded that the use of complete kit Hormonost progesterone concentration test was helpful for the early and late embryonic mortality detection.

The artificial insemination technician must update recent skills and knowledge. Hormonost ${ }^{\circledR}$ Micro Lab Farmers Test is important tool to improve conception and pregnancy rate in estrus synchronized cattle, by enabling accurate heat detection, conception, embryonic loss and pregnancy status. Hormonost $^{\circledR}$ a solution to invasive rectal palpation to diagnose which farmers disliked. To achieve higher economic return in cattle breeding, monitoring and correcting major causes of embryonic and fatal deaths is necessary. Further on-station research is recommended to address the limitations of this research. 


\section{References}

[1] Santos, J. E. P., Thatcherb W. W., Chebela R. C., Cerria R. L. A and Galvãoa K. N. (2004). The effect of embryonic death rates in cattle on the efficacy of estrus synchronization programs. doi: 10.1016/j.anireprosci.2004.04.015, p: 513-535.

[2] Prvanovic, N., Tomašković A., Grizelj J, Kočila P., and Samardžija M. (2009). Monitoring of early pregnancy and early embryonic mortality by ultrasound and determination of pregnancy-associated glycoproteins and progesterone in cows. vet. arhiv 79, 259-267.

[3] Mouiche, M. M. M., Sow A., Kalandi M., Nyabinwa P., Ouedraogo A. G. and Seadog G. J. (2016). Detection of embryonic mortality using progesterone and bovine pregnancy associated glycoprotein assays following artificial insemination of Gobra Zebu cattle in Senegal. Int'1 J. Clin. Biochem. Vol. 3 (1), pp. 143-150.

[4] Pohler K. G., Franco G. A, Reese S. T., Dantas F. G., Ellis M. D., and Payton R. R. (2016). Past, present and future of pregnancy detection methods. Department of Animal Science, University of, Des Moines, T. N. 2016. Applied Reproductive Strategies in Beef Cattle. Tennessee, Knoxville Iowa September 7-8.

[5] Diskin, M. G. and Sreenan J. M. (1980). Fertilization and embryonic mortality rates in beef heifers after artificial insemination. J. Reprod. Fertil. 59: 463-468.

[6] Friggens, N. C., Bjerring M., Ridder C., Højsgaard S., and Larsen T. (2008). Improved Detection of Reproductive Status in Dairy Cows Using Milk Progesterone Measurements. Reprod. Domest. Anim. 43: 113-121.

[7] Ball, P. J. H. and Jackson N. W. (1979). The fertility of dairy cows inseminated on the basis of milk progesterone measurements. Br. Vet. J. 132: 537.

[8] Bulman, D. C. and Lamming G. E. (1979). The use of milk progesterone analysis in the study of oestrus detection, herd fertility and embryonic mortality in dairy cows. Br. Vet. J. 135: 559.

[9] Foote, R. H., Oltenacu E. A. B., Kummerfeld H. L., Smith R. D., Riek P. M., and Braun R. K. (1979). Milk progesterone as a diagnostic aid. Br. Vet. J. 135: 550.

[10] Claus, R., Karg H., Zwiauer D., von Butler I., Pirchner F., and Rattenberger E. (1983). Analysis of factors influencing reproductive performance of the dairy cow by progesterone assay in milk fat. Br. Vet. J. 139: 29.

[11] Patel, M. D., Parmar S. C., Patel A. S, Makwana P. P., Rajput M. B., Patel J. H. and Patel A. G. (2016). Early Pregnancy Diagnosis in Dairy Animals. International Journal of Agriculture Sciences, ISSN: 0975-3710 \& E-ISSN: 09759107, Volume 8, Issue 11, pp.-1134-1136.

[12] Shamsuddin, M. M., U. Bhuiyan, P. K. Chanda, M. G. S. Alam and D. Galloway. (2005). Radioimmunoassay of milk progesterone as a tool for fertility control in smallholder dairy farms. Trop Anim Health Prod (2006) 38: 85-92.

[13] Butterfield, W. A. and A. W. Lishman. (1990). Progesterone profiles of postpartum dairy cows as an aid to diagnosis and treatment of reproductive disorders. Department of Animal Science, University of Natal, P. O. Box 375, Pietermaritzburg
3200, Republic of South Africa. S. Afr. J. Anim. Sci., 20 (4).

[14] Shearer, J. K. (2003). The Milk Progesterone Test and Its Applications in Dairy cattle reproduction. Animal Science Department, Florida Cooperative Extension Service, Institute of Food and Agricultural Sciences, University of Florida. http://edis.ifas.ufl.edu.

[15] Karl-Johan P. (2007). Milk Progesterone as a Tool to Improve Fertility in Dairy Cows. Doctoral thesis, Swedish University of Agricultural Sciences, Faculty of Veterinary Medicine and Animal Science Department of Animal Breeding and Genetics Sweden, Uppsala.

[16] Ayalon, N. (1978). A review of embryonic mortality in cattle. Journal of Reproduction and Fertility. vol. 54, no. 2, pp. 483493.

[17] Committee on Reproductive Nomenclature. (1972). Recommendations for standardizing bovine reproductive terms. Cornell Vet; 62: 216-37.

[18] Drost, M., J. E. Ambrose, M. J. Thatcher, C. K. Cantrell, K. E. Wolfsdorf, J. F. Hansen and W. W. Thatcher. (1999). Conception rates after artificial insemination or embryo transfer in lactating dairy cows during summer in Florida. Theriogenology 52, 1161-1167.

[19] Spell, A. R., W. E. Beal, L. R. Corah and G. C. Lamb. (2001). Evaluating recipient and embryo factors that affect pregnancy rates of embryo transfer in beef cattle. Theriogenology 56, 287-297.

[20] Jerome, A., and Srivastava, N. (2012). Prostaglandins vis-à-vis bovine embryonic mortality Asian Pacific Journal of Reproduction v 1 (3): pp 238-246.

[21] Van Cleef, J., Drost M., and Thatcher W. W. (1991). Effect of post insemination progesterone supplementation on fertility and subsequent estrous responses of dairy heifer. Theriogenology, 36: 795-807.

[22] Humboldt, P. (2001). Use of pregnancy specific proteins and progesterone assays to monitor pregnancy and determine the timing, frequencies and sources of embryonic mortality in ruminants. Theriogenology, 56: 1417-1433.

[23] Kastelic, J. P., Northey D. L., and Ginther O. J. (1991). Spontaneous embryonic death on days 20 to 40 in heifers. Theriogenology 35, 351-363.

[24] Cerri, R. L. A., Galvão K. N, Juchem S. O., Chebel R. C., Santos J. E. P. (2009). Timed AI (TAI) with estradiol cypionate $(\mathrm{ECP})$ or insemination at detected estrus in lactating dairy cows. J. Dairy Sci. 86, 181 (abstract).

[25] Hubbert, W. T. (Chairman). (1972). Committee on bovine reproductive nomenclature. Recommendations for standardizing bovine reproductive terms. Cornell Veterinarian, 62, 216-237.

[26] Silke, V., Diskin M. G., Kenny D. A., Boland M. P., Dillon P., Mee J. F., and Sreenan J. M. (2002). Extent, pattern and factors associated with late embryonic losses in dairy cows. Anim. Reprod. Sci. 71, 1-12.

[27] Lonergan, P., N. Forde and T. E. Spencer. (2016). Progesterone and conceptus-derived factors important for conceptus survival and growth. Anim. Reprod., v. 13, n. 3, p. 143-152. 
[28] McNeill, R. E., Diskin M. G., Sreenan J. M., and Morris D. G. (2006). Associations between milk progesterone concentration on different days and with embryo survival during the early luteal phase in dairy cows. Theriogenology 65, 1435-1441.

[29] Stronge, A. J. H., Sreenan J. M., Diskin M. G., Mee J. F.,
Kenny D. A. and Morris D. G. (2004). Post-insemination milk progesterone concentration and embryo survival in dairy cows. Theriogenology 64 (2005) 1212-1224.

[30] Klaus-I. A. 2008. Improve fertility and early diagnosis Salzburger Bauer 62, Issue 1-2, p. 50. 